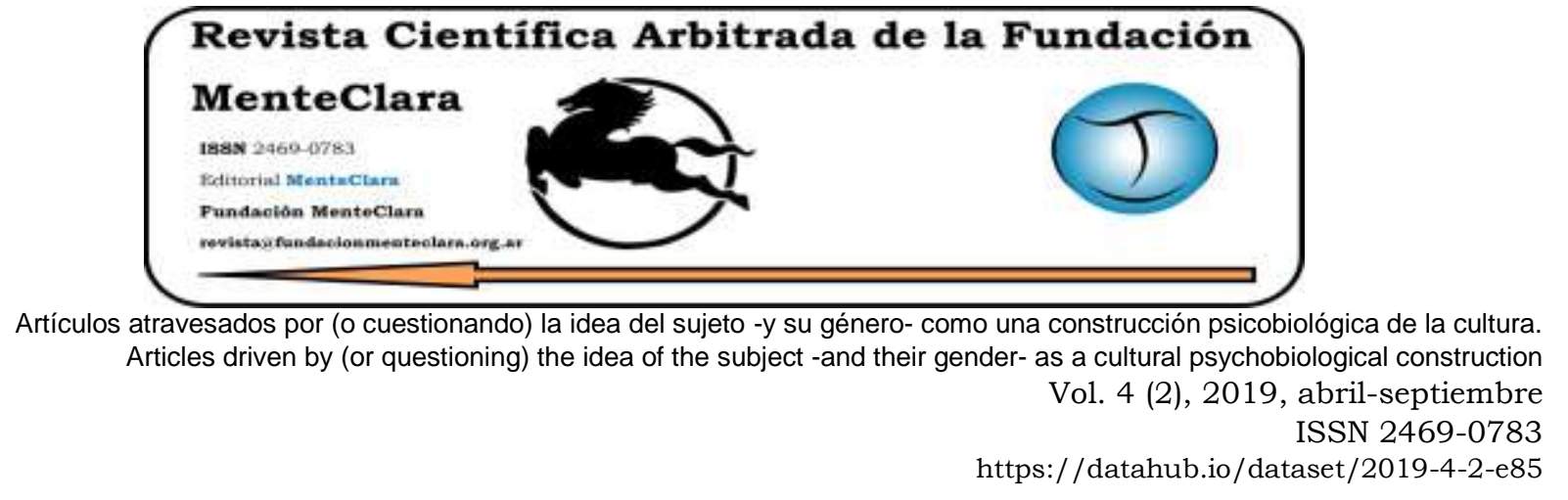

\title{
TOWARDS A COMPARATIVE POETICS OF BUDDHA, KABIR AND GURU NANAK: FROM A SECULAR DEMOCRATIC PERSPECTIVE
}

\author{
HACIA UNA POÉTICA COMPARATIVA DE BUDA, KABIR Y GURÚ NANAK DESDE \\ UNA PERSPECTIVA DEMOCRÁTICA SECULAR
}

Aparna Lanjewar Bose aparnablin@gmail.com

Department of English Literature, School of Literary Studies at The English and

Foreign Languages University, Hyderabad, India

Cómo citar este artículo / Citation: Bose A. L. (2019). "Towards a Comparative poetics of Buddha, Kabir and Guru Nanak: From A Secular Democratic perspectiven. Revista Científica Arbitrada de la Fundación MenteClara, 4(2) abril-septiembre 2019, 19-44. DOI: https://doi.org/10.32351/rca.v4.2.85

Copyright: (C) 2019 RCAFMC. Este artículo de acceso abierto es distribuido bajo los términos de la licencia Creative Commons Attribution 4.0 International License (CC BY 4.0). Recibido: 27/05/2019. Aceptado: 03/06/2019 Publicación online: 30/10/2019

Conflict of interests: None to declare.

\begin{abstract}
This article shows how democratic secular values existed 2500 years ago with the Buddha and later during the saint tradition in India, around 14th and 15th century, with Kabir and Guru Nanak even before they were legalized and enshrined in the Indian constitution. No other nation or community in the world probably possesses such a complete consequential philosophy of holistic liberation as India does. And that in a multilingual, multicultural multi-religious Indian ethos there can be a potential dearth of interdisciplinary religious studies or comparative religious departments is in itself the greatest paradox of our times. This paper therefore shall explore the revolutionary emancipatory potential in their philosophical beliefs and egalitarian worldviews that made them popular amongst all sections of the society. It's a known fact that all the three chose lives as commoners and used the popular language and dialect spoken of their times. All three questioned the efficacy of the Karma Kanda (Vedic rituals) and its hegemonic approach. Their ideological
\end{abstract}


orientations elicit a scientific and an open democratic debate on true nature of things. The rationality, equality and liberal ideology preached by them stands in binary opposition to irrationality, inequality and orthodoxy prevalent. The most important rationale and achievement, extracted out of all the three philosophies, is the psychological freedom ushered to those disqualified and despised because of caste, class, gender and opening up newer vistas of investigation and inquiry that could protect the weak against the onslaught of the strong and mighty. The teachings of Buddha, Kabir, and Nanak move beyond community, religion, language, culture and nation to provide a universal panacea and a paradigm of hope.

\section{Resumen}

Este artículo muestra los valores seculares democráticos desarrollados hace 2500 años por el Buda y más tarde durante la tradición santa en la India, alrededor de los siglos XIV y XV, por Kabir y Guru Nanak incluso antes de que se legalizaran y consagraran en la constitución india. Ninguna otra nación o comunidad en el mundo tiene una filosofia tan completa de liberación holística como la de la India. Y que en una idiosincrasia como la de la India, que es multilingüe, multirreligiosa y multicultural, pudiera haber una potencial carencia de estudios religiosos interdisciplinarios o departamentos de religiones comparadas es en sí mismo la mayor paradoja de nuestro tiempo. Además, este documento explora el potencial emancipador y revolucionario de las creencias filosóficas y cosmovisiones igualitarias que los hicieron populares en todos los sectores de la sociedad. Se sabe que los tres eligieron vivir como personas comunes y usaron el lenguaje popular y el dialecto que se hablaba en ese momento. Los tres cuestionaron la eficacia del Karma Kanda (rituales védicos) y su enfoque hegemónico. Sus orientaciones ideológicas provocan un debate científico y un debate democrático abierto sobre la verdadera naturaleza de las cosas. La racionalidad, la igualdad, la fraternidad y la ideología liberal predicada por ellos se encuentran en oposición binaria a la irracionalidad, la desigualdad y la ortodoxia prevalecientes. El razonamiento y los logros más importantes, extraídos de las tres filosofias, es la libertad psicológica que eleva a los descalificados y despreciados, debido a cuestiones de casta, clase, género y la apertura de nuevas perspectivas de investigación e indagación que podrían proteger a los débiles contra la embestida de los fuertes y poderosos. Las enseñanzas de Buda, 
Kabir y Nanak van más allá de la comunidad, la religión, el idioma, la cultura y la nación para proporcionar una panacea universal y un paradigma de esperanza.

Keywords: Buddha; Kabir; Nanak; Indian History; comparative poetics; philosophies; emancipatory potentials; secular democratic perspectives

Palabras Claves: Buda; Kabir; Nanak; historia de la India; poéticas comparativas; filosofias; potenciales emancipadores; perspectivas democráticas seculares 


\section{Introduction}

Today as we are heading more and more towards a progressive global community, virtues such as fellow feeling, kindness, loving sympathy and compassion are gradually getting replaced with individual self interests, hatred and bigotry. Oppressive hegemonic structures are transmuting into newer forms and even greater proportions, leaving humanity extremely vulnerable and susceptible to its distorted and gilded disposition at times. The culture of silencing dissent and encouraging discourses on war and animosity is rampant. While debauched forces are tirelessly working to rip humanity apart on violent religious political lines, the grand philosophic tradition too seems to be appropriated, regimented and tethered to squarely serve rabid fundamentalism, sectarianism and parochial religious interpretations perhaps more regressive than progressive. This is leading to proliferation of greater superstitious practices and baffling taboos.

Buddha, Kabir and Nanak belong to 3 different time frames of Indian history and yet what was it in their voice or speech that swayed the masses from all strata? What humongous strength their philosophical underpinnings must have to make their opponents consistently indulge in conspiracies, intrigue and subterfuge. What precisely was it that made them appear as potential threats to the rigid upholders of the Varna system? What is it that after several centuries behind they still continue to hold sway over popular imagination despite attempts at delegitimization by caste Hindu mainstreaming? My paper argues that rather than isolating these three historical greats within the narrow confines of their religious creed as most scholars on religious study do, thus mindlessly elevating one over the other and making sweeping generalizations, it would perhaps be more worthwhile to also look at the differences and the commonalities in their world views, besides their 
individualistic approach to prevalent disparities and evils. The three were revolutionaries in their own ways as their teachings challenged the existing social mores and encompassed the suppressed subaltern voices, placing the common man and his suffering at the centrality of their discourse. They deflated the hegemony of Sanskrit language by rejecting its sophistication in favor of a crude language and dialect understandable by the people. What is it that makes them so unique in the saintly tradition and why is it that they continue to hold relevance across centuries in our chaotic times?

The problematic of comparative poetics is nothing stranger than religious polemics. In that a lot of academic apparatus is built around some saintly figures with whom often comparison is elicited wherein also lies the danger of elevating one at the expense of derogating the other. There is huge body of literature surrounding the lives of the Hindu saints for instance which is quite exhaustive but lacks comparative approach. At times individual religious affiliations and beliefs tend to dominate and influence a researchers'world view on a vital subject of reverence thus arbitrarily dismissing any further exploration on core democratic issues where commonalities can be possibly drawn between egalitarian philosophies. This eventually, admits a schism between philosophies which can otherwise lead to some consensus often relegating to religious philosophical essentialisms both on the part of the readers and the researchers themselves by thoughtless dismissals and abundant elevations.

In the Bhakti tradition for instance, eliciting comparison of Nanak and Kabir is not new however, the researchers are lured to privilege one over the other. There are scant efforts on their part to compare the secular democratic possibilities or the quintessential goodness of their individual teachings, its uniqueness or the emancipatory potentials entailed within 
their revolutionary, ideological formulations. There is reluctance to contextualizing thevery spiritual ethos that possibly presupposes a liberated un- complicated, jargon free, understanding of pivotal issues confronting us today. Nevertheless, these philosophies still hold relevance and provide a universal panacea to heel bruises of those oppressed by the vague incomprehensibilities of classical religions.

Therefore, rather than probing into the mystical understanding, religious and spiritual aspects of the triumvirate, this paper attempts to dwell more objectively, on how the three enlightened men, revolutionized not just their own times but the entire gamut of human understanding about self and the world around them. The poetics and philosophies of Buddha, Kabir and Nanak entails dynamism, newer liberation discourses underpinning the foundation of secular democratic principles perhaps unheard of before in history of mankind.

Hinduism brought in the Varna Ashram Dharma. ${ }^{1}$ The Hindu Dharamshastras brought in the 4 Varnas -classes- namely Brahmin -priests-, Kshatriyas -warriors- Vaisya -traders- and Shudras -skilled unskilled labourers doing menial tasks- they are the present day savarnas. Those outside this four-fold ladder were the Ati-shudras. ${ }^{2}$ This was a hierarchy primarily class based. ${ }^{3}$ But each of the class became a regimented compartment accessible only by birth in other words, a caste. This caste system and later class system were given religious sanctions in the Hindu

\footnotetext{
1 This is one of the basic principles of Hinduism and peculiar to the Hindus. The duties of the caste are called Varna Dharma. The duties of the stages in life are the ashram dharma. The 4 ashramas or orders are Brahmacharya, Griasta, Vanprasta, sanyasi respectively.
}

2 These were also the Avarnas as they were outside the Varna 4 tier system while the rest in present times are the Savarnas.

3 In the Purush Suta of the Rig Veda, there is reference to the division of Hindu society into 4 classes where it is described that the Brahmin is born from the mouth of Brahma, the Kshatriyas from his shoulders, and the Vaisyas from his thighs and the shudras from his feet. Hence the Brahmins were more superior and the next came the Kshatriya, and so on. Also this division is according to the Guna (quality) and Karma (kind of work) that determine the caste of a man. 
texts written by Brahmins that spread the Brahminical theory that it was god made. The socio- political, economic religious restrictions laid down by the Brahmins in their religious texts were implemented by the kings / Kshatriyas. In other words, both religion and state joined hands to bind the lowest classes into social and cultural slavery and untouchability. Caste system in India was based on exploitation and an exploiting system adheres to a philosophy or system most favourable to it. Social inequality and untouchability were convenient and necessary for earlier rulers and so it was retained. Religious sanction and the cultural development and philosophy or system that supported exploitation were encouraged to flourish. This prevailed till the British advent in India and even much later.

The scriptures of Hinduism treated the weak and oppressed as enemies, by also indulging in vicious propaganda against them. They were mercilessly indulgent in hatred, malice, pride and scorn, against the Shudras and Atishudras who could never find a rightful place. Therefore, the values of liberty, equality, fraternity, rationality, ideas of democracy and socialism have no mythical significance in the society of the Hindus. It has no roots or normative basis in Hinduism. The literature of professed Hindu saints failed to accommodate these democratic principles. Rather, Racism, fascism, perversity occupy a larger domain. With the Islamic invasion, its function was to prop up the crumbling Hindu state and curb Islamic proliferation. It succeeded in spreading the Varna ideology. However, amidst the anarchy and chaos the period witnessed the decline of Hindu saints and the rise of Muslim saints. This was also the time when artists, intellectuals and protagonists emerged from lower classes/castes and women as Hindu oppressive machinery became rickety. But the Hindu rulers survived by accepting subservient positions under the Muslim rulers or by remaining sovereign. This led to 
the reappearance of the Varna system. The Muslim autocratic rulers retained the status quo for it ideally suited their own oppressive purposes. With the advent of British, the creative potential in society withered completely. The literature of saints belonged to this period of transition and is written against the background of centuries of warfare. The bhakti or the feeling of devoutness expressed by theseHindu saints could not spread the message of equality. And though the bhakti marg 4 was widely accepted yet different bands of devotees remained committed to the caste ideology. Belief in fatalism, doctrine of karma and rebirth was prevalent. Some bhakti poets like Tulsidas echoed the prejudices of upper classes. The catchphrase below bespeaks it all.

\section{Dhol gawar shudra pashu nari, teeno taran ke adhikari ${ }^{5}$}

With national enlightenment movement there was an awakening of the castes that challenged Varna system. Brahmins had the religious power and the Kshatriyas had political power. The intelligentsia of the Indian national leadership divided the enlightenment into 2 war zones- political and social movement and called those who organised social movements or theorised on agriculture or industry as stooges of British. The national movement turned into a form of historical mythological movement and ancestor worship. They rejected socialism.They wanted science and technology but clung to Varna system and invoked the Vedas. They wanted reform but resisted struggle for social democracy. And people who spoke of the misery of the masses were called as traitors and attacked.

Today interestingly, democracy and Varna system coexist in India. The country has two social orders. But democracy cannot coexist with caste/ class divisions for they mutually oppose each other. A healthy democracy

4 The path of devotion.

5 Ramcharitmanas p.778 
cannot have a Varna system. But if it exists in India then it only means that democracy here is farcical, existing in form and not in spirit. Presently it is a capitalist democracy pandering to the moneyed classesprivileged by religion, to monopolise wealth and the national resources.

In India capitalism to a large extent developed after independence as the huge divide of rich and poor is perceptible. Democratic socialism based on liberty equality and fraternity is the modern age mantra. But this philosophy has no roots in Indian psychic and mythical value structures. The literature of the Hindu saints has not provided any viable alternative.Therefore it in such crucial informant times that egalitarian teachings need to be taught and promoted. Nanak's philosophy holds greater relevance as also the philosophy and poetics of Buddha and Kabir from whom he drew inspiration to set up his own new order.

\section{Buddha}

Some 2500 years ago when democracy as a word was not even in the offing, it was the Tathagtha Gautam Buddha, who had spoken about equality of all humans; of caste, class as arbitrary barriers erected by the society; of social cooperation and active participation of all individuals in society. He had challenged the Vedic Brahminical religion of his times and established the Dhamma and Sangha. The Buddha was deeply affected and motivated for the moral advancement and betterment of the woeful lot around who were discriminated, tortured, and suppressed. This Dhamma had a solid foundation on humanistic and hermeneutic principles that negated injustices, oppression, fate, karma, destiny, idol worship, concept of God \& philosophy related to it. It had even unheeded the rebirth myth and rather formulated a revolutionary way of making one's life sublime in the same birth. The Dhamma meant a new code of 
living- an emancipated route that could emancipate one from misery and sorrow. It was thus the simplest yet most beauteous invention and a deeply ennobling analysis of human life which ruptured the age old concept of holiness and $\sin$. It was a philosophy born out of unselfish turmoil for oppressed/despised people and their moral elevation. The Dhamma became a way of life.

Hinduism, on the contrary had no solid foundation or founder. It flourished only after the massive destruction of Buddhism. The numerous Islamic invasions and the dominant Brahminical forces played a major role in the decline, destruction and loss of patronage to Buddhist institutions. The most colossal damage done was to appropriate the Buddha into the ritualistic Hindu folds by ridiculously claiming him as the $9^{\text {th }}$ avatar of Vishnu -one of the Hindu gods of the holy trinity, the others being Brahma and Mahesh-. Due to constant Brahminical conspiracies the Dhamma got exiled from its land of birth but became a national religion in many other countries. Buddha's poetics questioned the inequalities based on birth and gender and welcomed both men and women into the Sangha. He never felt the need to make tall claims like "yada yada hi dharmasya glanirbhawtu bharat"6 nor did he proclaim himself as the only true liberator of mankind. The institutionalized caste framework was found disgustingly repugnant and instead the rule of equality was perceptible as Dhamma was constituted on the basis of freedom, equality, fraternity and social justice. Thus an intellectually and scientifically advanced ideology incorporating the strongest human values of wisdom, nature, loving kindness and compassion -pradnyasheel- karuna- was propounded and practiced by Buddha. The 
philosophy of 'bhawatu sabba mangalam'7 was well loved and received. The democratic Dhamma approach was accepted by all.

Buddha the great compassionate prophet saw the concentration of wealth, the fierce struggle to acquire it, the violence, the growing inequalities, sorrow, misery and servitude. He condemned exploitative structures however, inequalities were pervasive. He showed where sorrow originated and gave prescriptions to eradicate sorrow. Since the prevalent social order was firmly entrenched by the doctrine promoting Varna and class. The entire social fabric was torn asunder by inequalities. The Buddha's sangha offered a refuge to people from different castes and classes to peacefully coexist in a kind of social democracy. The Bhikus were from all classes -oppressed, oppressors and rulers too. They enjoyed a happy life and participated in the welfare of the masses. However, Buddhism could not be the natural disposition of an exploitative state or society founded on inequalities, as it questioned the rationale of such inequalities. Therefore, with extreme deceitand manipulative methods the karma theory was imposed by the Brahminical minds where birth was conceived as being founded upon the deeds of previous birth -karma-, upon the good or evil actions of previous lives, upon divine justice. People with wealth and power claimed to represent the divine while those condemned to sorrow, misery, untouchability were found damnable, denied any form of deliverance and salvation and thus left out of the process of social production.

Several centuries back Buddha spoke of man- woman equality. He welcomed women in the Sangha who came from all strata of society. He established a community of women as nuns called the Theris. Their 
compositions $^{8}$ give important information about the genuine folk religionas opposed to the Vedic and Brahminical texts. This was a clear indication that the Buddhists were closely in touch with the popular strata of the Indian society than any other existing religious movement of the time.Buddha negates god's existence and propounded the scientific path.The 4 noble truths:

1. All is suffering / Dukkha

2. Suffering has a cause

3. It can be ended

4. There is path to that end which is the 8 -fold path. This entails right faith, right resolve, right speech, right action, right living, right effort, right thought and right concentration.

The human mind keeps craving for material things and this is the cause of misery. Buddha affirmed that complete liberation from Samsara was possible. This liberation is 'Nirvana' and many of the utterances or uddanas of both the Theri and the Thera express joy of achievement of this state. It is cessation of all suffering when all desires and cravings are eliminated. Instead of seeing a person in terms of soul Buddhism describes what makes a person as a series of things and events: physical as in the body, feelings, perceptions, innate disposition and consciousness.

Buddhism thrived when the state permitted anti spiritualism, atheism, rationalism and a progressive attitude to grow. But when the exploitative state found it inconvenient, it destroyed it with the help of military power or devious means. The fault therefore lies not with a particular caste but with the Hindu feudal system. The entire system was founded on monarchy. The age itself gave rise to and

8 The poetic compositions of the elder female nuns were called as the Therigathas. Autobiographical in nature they date as early as $6 \mathrm{BCE}$ in the Pali canon these are classified as part of these are part of the Khuddaka Nikaya. The compositions by the male monks were called as the Theragathas. 
nurtured the doctrine of sacredness, holiness and divinity being revealed or appearing as vatar or incarnation. ${ }^{9}$

Buddha's Dhamma could have led the society to democracy with its basic pluralistic principles. Its philosophy is dynamic, progressive revolutionary and atheistic unlike theism and spiritualism, it could never be the mouthpiece of static absolutism.

\section{Kabir}

V. Raghavan says Bhakti is the "democratic doctrine which consolidates all people without distinction of caste, community, nationality or sex"10 The commonality between the Bhakti poets and the numerous regional articulation of Bhakti was the idea of devotion to a personal god. It spread as a movement across north and south India. Among the bhakti movement, the Hindu Bhakti movement makes a distinction between Nirgun and Sagun; Vaisnava and Sant tradition. And within the Sant tradition there are glaring differences which are perceptible. The more liberal Bhakti has for its entire corpus an identifiable god who is just and one for all, who makes no distinctions. Such liberal Bhakti poets identified themselves with the agony, pain and suffering of the commoners. They were not social reformers or revolutionaries nevertheless through their dissenting voices and protestations against the social ills of their times, they lashed out at the institutions that stood in way of human progress. They broke all boundaries of regimentations by daring to question the existing ideologies codified in the name of religion. Their social paraphernalia to a large extent contributed to their liberal ideological formulations. Secondly, the

9 Baburao Bagul. In Arjun dangle (ed.) Poisoned Bread. Orient Longman, 1992.p.274 
eastern parts of Uttar Pradesh including Kashi from which they hailed especially in the $15^{\text {th }}$ and $16^{\text {th }}$ century were proactive for Bhakti and Sufism. This became a training centre to them for liberal thoughts. How much of Bhakti really supports the ideals of democracy, tolerance and how much is egalitarian is something one may ponder on, no doubt. But Kabir stands as a mystic who tried to bring about Hindu - Muslim reconciliation in a downright confrontational manner. He rejected the usefulness of the scriptures of both the religions because they were misused and misrepresented by the so called guardians of both the religions namely the Brahmins and the Mullahs.

Kabir's life and birth is surrounded by many legends. He historically existed in the late $14^{\text {th }}$ century when Delhi and the whole of North India became weak due to unending animosity between Hindus and Muslims. What was then needed was an alternative orientation of spiritual thought. Then came the bhakti movement with Mirabai, Surdas, Raidas and others. It is said that Kabir was a product of the bhakti school. He lived and flourished in Banaras. It is also said that he was the disciple of Ramanand- a Vaishnavaite guru. But he departed from his teacher in as much as he propagated thoughts which were incompatible to Brahmanism. In those horrendous times of hatred and bigotry, he could evolve a creed of unity between historical rivals, the Hindus and Muslims, and had great following amongst both; it speaks of his secular democratic vision. A Julaha by profession who earned his living as a weaver. He was a self taught person who united Ram and Rahim and preached the existence of one God. His poetry has a terse, pithy, earthy touch with regular use of vernacular borrowed from Braj, Bhojpuri, Avadhi dialects of Hindi.

His philosophy synthesises Hinduism and Islam. However, scholars maintain that he questioned them both and also the need for a holy book. 
He perhaps questioned the need for religion too and rejected the hypocrisy of misguided rituals evident in his times. Most importantly he ridicules and exposes the fallacy of Hinduism that appropriates within its fold great personages as Avatar. He rebukes them saying "Buddha didn't put down devils." In Kabir there is a strong resentment against social discrimination and economic exploitation.Charlotte Vaudeville argues that his philosophy is seeking the absolute -in whom all contraries merge- ${ }^{11}$ The Nirguns that denies distinction between soul and god and endorses the idea of true divinity lying within a man himself. But if God is within then that would be a call to abolish all external bhakti. One needn't dwell into this contradiction. However, the possibility of Sufism and bhakti having mutual interactions is undeniable.

Kabir's verses were incorporated in the Adi Granth and remained one of the major influences on Guru Nanak who later founded Sikhism. As the later in its earlier stages was a movement within the Hindu tradition some scholars disagree upon this but W.H Mcleod places Kabir and Nanak into the Sant tradition of North India. Some critics have called Kabir a misogynist whereas in contrast Dass in Rag Asa of Adi Granth reflects on Kabir asking a married woman to stop covering her face and not adopt such practices. ${ }^{12}$ He further elaborates that woman is the human female principle allegorical of his own soul and Rama the loverhusband consort. ${ }^{13}$ Kabir's thoughts on women as being obstacles in the path of spiritual progress, if analysed carefully could also stem from his personal rather than general observations as the same Kabir in Bijak chides the Hindu Brahmin saying:

11 Charlotte Vaudeville in Karine Schomer and W. H. McLeod(eds.) The Sants: Studies in a Devotional Tradition of India, Motilal Banarsidass Publishers, 1987 p. 26

12 Nirmal Dass. Songs of Kabir from the Adi Granth, State University of New York Press, p.1991 $147-148$ 
"By putting on sacred thread one becomes a Brahman

what hast thou given women to wear?

She from birth is sudra"14

This renders a clear acknowledgement of women's social positioning in Brahminical patriarchy as well as exposes their hypocrisy.

1. O Sants! I have seen the way of both.

Hindus and Turks heed no warning: to all the taste of their desires is sweet.

2. Hindus keep fast on Ekadasi* and taste only singaras* and milk They abstain from grain, but do not check mind's desire: next day they eat the flesh of beasts.

3. Turks keep fast and hours of prayer: they cry aloud in the name of god

How will they find paradise? When evening comes

they slaughter fowls.

4. Hindu and Turk, each has renounced his mercy in his heart

One kills by halal* one kills by jhatka*: but fire is

kindled in both their homes

5. For Hindu and for Turk there is one path, so the

sat-guru has taught

Says Kabir listen OSants: Cry 'Rama' Cry 'Khuda'

it is one. 15

14 Sabda 84, Bijak p. 135

15 Sabdas 10 Bijak p. 99. Ekadasi is the 11th day of each half of the month is observed by the Hindus generally, and especially by vaishnavas, as a solemn fast. Singara is the water chestnut. Muslims when they slaughter an animal for meat or sacrifice before killing the victim repeat a special formula that is called halal. Alternately it's the slow cutting of the throat to allow blood to drain out. The Jews call it kosher if not killed this way it is said to be haram or unclean. The Hindu way to slaughter is by a sudden jerk and only such meat is lawful for sacrifice. This method is called the jhatka. 
Therefore, clearly Rama is not the son of King Dasharatha but a union of Ishwar and Allah. Kabir was vehemently attacked by both and persecuted for his views because he spoke the truth. Kabir becomes the voice of the voiceless, a mouthpiece of the common masses, a rebel against social discrimination and economic exploitation. He rejects the double standards and misguided rituals in religious practices. The beautiful allegory of a running hare falling in the ravines set in one of the sakhis ${ }^{16}$ explains the condition of people running after allurements and falling in the mire of greed, illusion, materialism, racial intolerance, vanity, religions, and pride.

The language used in the Bijak is one spoken in neighbourhood of the Mirzapur Gorarkpur. The writing is Kaithi. Kabir spoke the Mirzapuri gorakhpuri dialect, the purbia boli or the language of the east which was difficult to understand. It was the language of the rustics resented by the Brahmins. Here again one finds abandonment of Sanskrit in favour of language of the common people. His approach to democratisation of language is reflected in the fact when he says "Sanskrit is like the water of a well, while Bhasha is like the flowing water of a river." Perhaps this abandonment of language in favour of popular dialect of the masses is the important reform he set to bring. The importance of Kabir rests on the enormous influence he exercised on the Sikh religious thought i.e.Sikhism. Infact $2 / 3^{\text {rd }}$ of the Granth is Kabir. About Kabir's inclusion in the Adi Granth, Karine Schomer says "the selection must have been made on the basis of conformity to the moods and motivations of the Sikh religious community at that particular stage of development"17 Thus the Kabir of the Guru Granth as he appears is a "householder" saint emphasizing company of good people. Vaishnava Kabir is swayed by

16 Sakhi 44, Bijak p.188

17 Kabir in Guru Granth sahib: An exploratory essay,1979 p.77 
love's intensity while western Kabir is devotionally oriented. Banaras Kabir is different from all these. Kabir's initiation by a Brahmin Ramanand can be an all too neat way for a particular kind liberal theology to incorporate -and perhaps to co-opt- the charishma of Kabir ${ }^{18}$

Kabir perhaps influenced his own teacher Ramanand who coincidentallyhas no work in Bhasha. The latter a strict adherent to caste practices, he spoke to non- Brahmans only through an intervening screen. After Kabir, one finds a Rajput, a Chamar, a prostitute, a butcher being admitted by him as his pupils. This reflects the revolutionary impact Kabir had even on the hardliners. It is said that Nanak through his wanderings came across 3 sadhus possibly the emissaries of Kabir. There is also a record of Nanak meeting Shaikh Kamal Kabir's son. The story of dispute over Kabir's remains and its settlement reappears in Guru Nanak. There are numerous allusions to Kabir in Janam sakhis and in the family of Nanak, Kabir was held with veneration. Nirmala and Udasi the professed followers of Nanak regard Kabir as their Guru. A hymn from Nanak's follower, Dulan Das goes thus

Nanak nam Kabir mata hai: so guru praghat sunai

Dhruve prahlad ye hi ras mate: shive rahe tari lai

Which means "Nanak is the name of the religion of Kabir: the guru has told me so openly Dhruv prahlad was intoxicated in that juice: and Siva remained in Samadhi."

The second hymn from Guru Gobind Singh goes thus

Kabir panth ab bhayo khalsa which means "the religion of Kabir has become Khalsa"19 
To a religious hardliner like Tulsidas too Kabir is real and he writes in his Wane Patr

Sarawa sto Kabir ne kaha Kabir sang the real thing

Shesh bacha so surda laha whatever little remained was held by Surdas

Tulsi ram nan pad gaha Tulsi sang the praise of Ram

Interestingly, Nanak and his successors were natives of Punjab but the Punjabi hymns of the Granth are few comparatively. Nearly $70 \%$ are in Hindi and many contain words of Gujrati, Marathi and other southern dialects. The 15 Bhagats have largely borrowed from Kabir. Therefore, despite scholars refuting, Kabir's influence is undeniable and his popularity till date is immense. But as stated earlier the purpose of this paper is not to show who was greater by influencing the other rather it is more to add up to the ongoing debate on how egalitarian, pluralistic and democratic principles find their echo in progressive poetics and ideologies. A closer reading of Kabir reveals that he is not an abusive religious revolutionary.His teaching is based on original thought. His primary concern was to drive home his message of unity. Religious tolerance and the brotherhood of mankind were the chief lessons he sought to inculcate. His religion is the religion of compassion for all, like the Buddha.

Kabir's contemporaneity can be measured by the manner in which he deals with each organised dominant and oppressive religion made extremely sectarian and so presents the errors of the adherents. He refutes the Vedas, the Hindu system of philosophy and emphasises how these beliefs and their accompanying rituals are powerless to save man. Like Buddha's Anichya or theory of impermanence, Kabir postulates that nothing in the universe is true and real, it is illusory. To Kabir all the 
regulations of caste and religious rituals are pretentious and misleading follies that only serve to confuse men's mind, blinds them and fosters vain self importance. Thus he wages a relentless war with the evils of his times and remained in constant conflict with the orthodox religious heads of his times. Like Nanak he denounced idolatry, caste system and like Buddha advocated Ahimsa and the path of Nirvana. Nanak and his successors to a large extent imbibed the religious principles of both Buddha and Kabir.

\section{Nanak}

Many of the concepts Nanak shared wit h earlier and contemporary religious figures including Kabirs' show evidence of his thought being closely aligned to the Sant tradition of Northern India. There is no doubt that much of it was derived directly from this source ${ }^{20}$ Guru Nanak spoke about the Vedas, Puranas, Shastras, Smritis and various philosophical schools. He spoke of the holy trinity, the Naths, siddhas. There is no headlong confrontation with these doctrines nor a willing acceptance is what some critics feel. Contrarily, Nanak refuted the consecrated value of the scriptures and invalidated the belief that reading and hearing the Hindu scriptures could ensure salvation to mankind. Nanak set aside the authority of the Vedas for its lack of rationale and debunked them as incomplete and conditional.

He saw men perform religious rites and rituals believing that it would render them comfort and peace but both were farfetched. Where he neither condemned nor repudiated existing religious philosophies as some feel, the hagiographic detailing about Nanak's life reveal that he picked up that which was essential and valuable, that was free from 
religious and polemical jargon, something that was more simplified for the common man's understanding. The detailing also further amplify the importance rendered by him to the fundamental and essential truths that could serve as the foundational premise for a new order he was to establish.

The stone and idol worshipping Hindu culture was vehemently questioned by Nanak time and again. He detested the numerous images and deities in favour of one formless, shapeless colourless omnipotent supreme being who dwells in all creation. The Brahminical Karma Kanda -ritual services- was stiffly opposed as also the scriptural indoctrination of the gullible masses. The religious rites, yagna's and sacrificial rituals were ridiculed for the endorsement of love of the one and only supreme being and for the greater love and service of humanity at large. These rites and rituals were meant to be performed only by the Brahmin priests and pundits and this was detested by Nanak who scoffed at this Brahminical hegemony. There arrogance pride and haughtiness was challenged by him time and again. When the mind is full of pride and sin, how can it be purified just by a holy dip in the sacred rivers? For such a person even the holy waters fail to redeem, said he. Like wise the Trinity of Brahma-the creator, Vishnu-the sustainer and Mahesh-the destroyer, was disfavoured by Nanak in favour of a more selfless service to be rendered to humanity which needed more practical resolutions to their misery.

If the heart is not cleansed of ego how would holy pilgrimage helpor how would wanderings to sacred places enable one to wash off misery ${ }^{21}$ True faith remains in Nam and Shabad feels Nanak. ${ }^{22}$ When he says my

21 Guru Granth. 1102

22 Guru Granth. 687 
being is filled by the shabad that he may not find another life he seems to be blatantly denying the rebirth theory. ${ }^{23}$ What is indeed interesting about Nanak's emancipatory creed is that rather than claiming to be divinely inspired, he preferred to claim himself as the bard who could sing the glory of the divine. Rather than proclaiming himself as the son of god, the alpha and the omega the first and the last, the beginning and the end ${ }^{24}$ or worst still as an avatar he humanises himself.Neither Nanak nor the successors to his metaphysical realm had anything to do with such claims.The times of Nanak and the preceding period were turbulent and saintly men were very conveniently bracketed as Avatar. However, the word assumes an altogether different recasting as the name for the superior formless God.

Guru Nanak rejects external authority,ceremonies, religious texts, pilgrimage, ritual bathing and many such things.However, many historians seems to miss out why he got into the enterprise of gathering a community with numerous institutional structures. G. S. Mann feels that by merely emphasising the religious side of his life and legacy, historians like Mcleod, seems to undercut the importance of such institutional structures on one hand, and seem to point toward it being some sort of "Hindu group centred on meditation, on the other." 25 For Nanak the lives of the people were oriented around three things namely meditation, search for liberation and work in the fields. His poetics has the interwoven vision of liberation and landscape which is replete with images of soil, plants, animals and birds. He finds beauty in creation. His emphasis on monotheism and belief in human equality, and his social 
commitment distinguishes him from the Hindu saints. His discomfort with corruption and vices of his times is well expressed thus

Raje sih muqadam kute, jai jagain bethe sute 26

He couldn't bear to see the hapless innocent people bearing the brunts of merciless conflicts and repudiated violence

Je sakata sakate ko mare ta man rosu na hoi /

Sakata sihu mare pai vagai khasmai sa pursai ${ }^{27}$

At Kartarpur, his home served as the sacred place and the destination of pilgrimage for people and the initiation ceremony brought many new people into the community fold. The recitation of his poetics were followed by community cooking and sharing of food. The revolutionary concept of langar-communal meal- also distinguishes him from the other Hindu saints. His affection for the downtrodden is reflected in the lines

Niche andari nich jati nichi hu ati nichu, nanaku tin kai sangi sathi vadia siau $k a$ ris $^{28}$

Nanak wrote in the language of the people.And for the people to join a Guru who dreamt of building a corruption free, an oppression free society, who stood for human equality, was a viable option rather than being part of an oppressive Brahminical Hindu hierarchical order or the exploitative feudal regime then prevalent.His followers were called as Nanak Panthis. Modern scholarship underlines Nanak's affinity to Nirgun Bhakti of which Kabir was an exponent. Like Kabir, in Nanak too, the Rama and Krishna do not embody the mythical, classicistic Rama / Krishna, sons of Dashrath and Vasudeva, rather they are names of the formless one. And whenever he harks back to the classicistic personages 
they become ordinary mortals divested of all super human powers. Mcleod examines the teachings of Guru Nanak and comes to the conclusion that "In Guru Nanak as in Kabir there is the same rejection of exterior forms, the same insistence on the need for inward devotion and its sufficiency as the sole means of liberation." 29

\section{Conclusion}

The works of Kabir and Nanak present a system of interrelated ideas which are independent of all other systems of religious ideas. Their positions are similar not because they belong to the same tradition but because each had a new path to show to his contemporaries. Similarly, Both Buddha and Nanak revolted against the Brahminical ills and rituals, against the caste system, and preached equality, humanity and service to mankind. It is only through one's deeds in life that one can proclaims one's caste and therefore truthful living is advocated by both. Nanak accepted Buddha's four-fold noble truth and eight-fold noble path. In fact, any believer in humanity and equality cannot fail to be not influenced by Buddha. The concept of Shunya for Buddha meant the indescribable and not emptiness. This Shunya to a great extent has its realisation in Nam. The Nam is 'Wahe Guru' the preceptor who is God himself an indescribable wondrous being whose creation creates a sense of wonderment. It is Nam that sustains all. The world and the absolute are Shunya. Everything is Shunya. Both Nanak and Buddha used the language understandable by the common masses. Nanak used Gurumukhi while Buddha preached in Pali language. 
Today, when we focus on the challenges of our times we find a desperate need to recall all those secular, egalitarian, democratic values and humanitarian principles rendered by these three great men of history who represented three different time frames. They all suffered heavily for their revolutionary approach namely, valuing human equality and dignity, acceptance of particular religious orientations, a concern for how they might become resources for consolidation of an open democratic and dialogic interaction. Their ultimate involvement with the audiences, their mass appeal, their approach to problem confronting their times, the prescriptions and antidotes given by them to the heterogeneous masses from different religious beliefs and orientations, their efforts to question the sanity and sanctity of scriptures, their continuous challenge to Brahminical hegemony, to communicate with the audience in their native languages, to empathise with the common man and his problems, makes them heroes for all times. Their life and living, their poetics and philosophy has stood as a testimony for innumerable generations to come. Their popularity in popular culture only testifies further to their living presence.

Lastly, it needs to be mentioned that we incidentally, live in a country which in many ways is religiously divergent and we have very few scholars who identify themselves by the discipline as students or scholars of religion. There has been successive evaluation of religions by historians, sociologists and anthropologists but today our universities have no place where such interdisciplinary religious studies or faiths can be promoted. Religion has become a fixture. Barring few exceptions Indian universities have no place for comparative religion and this is the greatest paradox of our times. 


\section{References}

Ahir, D. C. (1972). Buddhism in modern India. Nagpur : Bhikkhu Niwas Prakashan.

Ambedkar, B. R. (1957) The Buddha and His Dhamma. Bombay: Siddhartha College publication.

Bose Lanjewar, A. (2006) Contextual and Sociological Challenges to Buddhism in 21stcentury. in Muktigatha (special issue) Nagpur: Diksha Bhoomi, Sept.2006.122128.

Dangle, A. (1992) Poisoned Bread. Bombay: Orient Longman.

Grewal, J S. (1979) Guru Nanak in History. Chandigarh Punjab University

Gurinder S. M. (2010) Guru Nanak Life and Legacy: An Appraisal. Journal of Punjab Studies Volume 17.1-2

Hawley, J. S. (2005) Three Bhakti Voices. New Delhi: Oxford University Press.

Hawley, J. S. And Mark J. (2004) Songs of the saints of India. New York and Delhi:Oxford University Press.

Kabir, 15th cent., Shah, A. (1917). The Bijak of Kabir. Hamirpur: A. Shah.

Mcleod, W. H. (1969) Guru Nanak and the Sikh Religion. Oxford: Clarendon Press.

Mcleod, W. H. (1997) Sikhism. London; New York: Penguin Books.

Schomer. K. (1979) Kabir in the Guru Granth Sahib, An exploratory essay. In Sikh Studies: Comparative Perspective on a Changing Tradition, edited by Mark Juergensmeyer and N.G. Barrier. Berkeley: Berkeley Religious Studies Series and Graduate Theological Unions. 